\title{
A NEW PERSPECTIVE ON THE GENEALOGY OF COLLECTIVE ACTION THROUGH THE HISTORY OF RELIGIOUS ORGANISATIONS
}

\author{
François-Xavier de Vaujany \\ CERAG (UMR CNRS 5820) \\ Grenoble University (IAE) \\ 150 rue de la Chimie \\ 38040 Grenoble \\ FRANCE
}

devaujany@iae-grenoble.fr

\begin{abstract}
This article puts forwards a "reorientationist" perspective about the genealogy of collective action and artefacts deployed for its orientation. It draws on the history of religion and religious organizations as elaborated by several promoters of the so-called "new history" in France. These historians (mainly medievalist) can be helpful in writing a different genealogy of contemporary models of collective action (i.e. ways of reaching a goal together) and their institutional context in western countries. They can also facilitate a critical understanding of long-range organizational dynamics.
\end{abstract}

Keywords: Genealogy of collective action; history of religious organizations; history of managerial practices; new history; Catholic Church. 
Calls for cross-fertilizations between history and organization theory are far from being new (Booth and Rowlinson, 2006). Business history (Yates, 1997), management history (Brady, 1997; Wren, 2001), general history or history of religions (Weber, 1978; Kieser, 1987) have long been invited to collaborate with organization theory. This has resulted in either "supplementarist" (longer time span in organization studies), "integrationist" (new or stronger links between organization theory and history) or "reorientationist" (deep criticism and renewal of organization theory on the basis of history) positions (Usdiken and Kieser, 2004).

Here, we would like to stress an avenue for further cross-fertilizations with organization theory: the history of religious organizations ${ }^{1}$, in particular as sustained by some promoters of the so-called French “new history" (mainly appearing in the 60's and 70's). This school is the direct continuation of the "Ecoles des Annales", and is mainly condensed in the famous book L'histoire nouvelle edited by Jacques Le Goff in 1978. The main tenets of this school deal with the conceptualization of time in history (the treatment of "longue duree" in historical work), the room left to marginals, institutional and structural dimensions of history, material culture, the writing of historical narratives, or the history of mentalities ${ }^{2}$.

Many 'new historians' have been working on the history of religious organizations, in particular the history of the Catholic Church and its various enclaves (e.g. the Roman Curia and abbeys). The material they have been providing about monastic organizations, commercial practices, institutional influence of the Church on emergent Capitalism, the social doctrine of the Church, etc. could be helpful in the elaboration of a different perspective on the genealogy of collective action (i.e. ways of reaching a goal together) and artifacts related to collective action.

Our project here is to suggest a means of developing a true genealogy of collective action (in particular modern and contemporary organizational action ${ }^{3}$ ) through the analysis produced by this rich historical school. According to Foucault (1977: 139), "genealogy is gray, meticulous, and patiently documentary. It operates on a field of entangled and confused parchments, on documents that have been scratched over and recopied many times". Many religious texts treated by new historians (such as monastic rules or status) are the epitome of this (see Lapierre, 1982). We do not aim at identifying origins of collective actions or genuine proto-

\footnotetext{
${ }^{1}$ The sub-stream of history of religion interested in religious organizations such as monasteries, bishoprics, congregations, etc.

${ }^{2}$ There are strong common points between the axis of renewal advanced by Le Goff and his colleagues for history, and the topic of collaboration advanced by Booth and Rowlinson (2006) for Management and organizational history.

${ }^{3}$ Indeed, "organization" is a very 'modern' word (see the Trésor de la langue française) for a history of its etymology).
} 
organizations, but more at shedding light on points of rupture in the long history of collective action and artifacts deployed for its management ${ }^{4}$. We will thus not "demonstrate that the past actively exists in the present, that it continues secretly to animate the present, having imposed a predetermined form to all its vicissitudes" (Ibid: 146). In contrast, discontinuities, evolutions in the modalities of collective actions, renewal in the relationship with rules, and deep changes in the artifacts used for the orientation of collective action will be emphasized. For several western countries ${ }^{5}$, we believe that historical narratives provided by new historians can be a way to deconstruct usual discourse about management history and organization history. A "reorientationist" stance will be thus defended.

Indeed, it is worth noting that with the institutionalization of the merchant and the banker (Le Goff, 1997); the development of commercial and financial techniques (Le Goff, 2001; Verger, 1973); the emergence of longstanding archetypes about collective action (which still feed the imagination and intervention of some practitioners in Occident) (McGregor, 1960; Mutch, $2006 \mathrm{a}$ and $\mathrm{b}$ ); the design and diffusion of technical innovations and managerial tools (Bazin et al, 1998; Giffard, 2001); and the means of their distribution (de Vaujany, 2006): the Catholic Church and its enclaves played a role of primary importance in several points of rupture. Numerous shifts in the modalities of collective action and artifacts related to its orientation have been developed, inhibited or catalyzed by religious organizations (in particular the Church). Despite this, religious organizations have been largely ignored in the analyses, models and genealogy of collective action in general, and contemporary managerial practices in particular (Kieser, 1987; Swanson and Gardner, 1988; Carruthers and Espeland, 1991; Carmona and Ezzamel, 2006; Mutch, 2006 b and c).

Pursuing this line of thought, this paper focuses on justifying and clarifying the following research questions:

i) How have collective actions been constrained and/or enabled by religious practices? Our aim is to shed new light on the institutional shaping of collective action by the Catholic Church (itself subject of numerous points of rupture).

ii) How can past and current Church practices constitute, per se, a stimulating research subject for the study of collective action (in particular managerial practices)? The goal here is to study the history of religious organizations as a specific field, which will then be compared and contrasted with classic for profit

\footnotetext{
${ }^{4}$ According to Foucault (1977: 145), "History is the concrete body of a development, with its moment of intensity, its lapses, its extended periods of feverish agitation, its fainting spells; and only a metaphysician would seek its soul in the distant ideality of the origin".
} 
organizations. The goal is also to raise provocative and insightful questions about organizational continuity. Does it make sense to study the history of a very old organization (e.g. the Roman Curia)?

Drawing upon the thoughts of major French historians ${ }^{6}$ (Le Goff, Vovelle, Pesez, Verger, Pacaut, Levillain, Duby...) this essay aims at showing the relevance of our twofold question.

\section{THE ROLE OF THE CHURCH AND ITS ENCLAVES IN THE RENEWAL OF COLLECTIVE ACTION}

This is not a remarkable notion for societies long under the domination of Catholic beliefs and Catholic actors. The Roman Curia (i.e. the central administrative headquarters of the Catholic Church, located in the Vatican, see Levillain, 1994) and the numerous enclaves of the Church (like monasteries, congregations or bishopric) were at the origin of the development and institutionalization of new models of collective action in western countries. During the modern period, the Church has at times inhibited and at other times catalyzed the promulgation of proto-managerial artifacts and techniques (i.e. artifacts and techniques preceding and influencing those of the industrial revolution).

\subsection{Monasteries and the genealogy of proto-bureaucratic models of collective action}

According to Wren (2001), households, tribes, armies, governments and, more specifically for Western countries, the Church (and its various enclaves), have preceded and influenced the emergence of contemporary models of collective action. Long before the "compania" (as described by Hatchuel and Glise, 2003), monastic enclaves played a role of primary importance in the genealogy of modern collective action. As we are reminded by Racinet (2007) the Middle Age has been repeatedly called the "age of monks".

Monks contributed to the rise of bureaucracy in western countries ${ }^{7}$. A major event in this evolution, and one worthy of mention, is the emergence of the Benedictine rule during the $6^{\text {th }}$ century and its broad diffusion from the $8^{\text {th }}$ century onward.

\footnotetext{
${ }^{5}$ Our analysis applies mainly to western countries, in particular France, Spain and Italy.

${ }^{6}$ All designers, promoters or heirs of the "new history".

${ }^{7}$ And the 'disciplinization' of society as described by Foucault (1979).
} 
The Benedictine reform cannot be understood without making reference to what preceded it: the Eremitic and Sarabaït movements (Berlioz, 1994; Pacaut, 2005). These movements were composed of individuals (or groups of individuals in the case of the Sarabaïts), lacking specific rules and infrastructure, living their faith around a charismatic leader. Members lived and evolved in isolation from the rest of the world in places such as the Lybian or Egyptian deserts. They did their utmost to survive on what nature provided them, or more rarely, they relied on human generosity.

With the Benedictine Rule (a short book of around 12000 words divided into 73 chapters) arose a new form of religious collective action (Fauchez, 1994). The group now organized itself inside a monastery. It alternated work and prayer. The collective lived in autarchy, far from "normal" society. It is also worth noting that the development of Benedictine and associated orders embody a major shift. With them appeared the first religious communities whose contributions were punctually and incidentally productive (oriented towards the agriculture and/or intellectual activities, such as the creation of manuscripts or the development of crafts). With them also arose a new form of collective action, autonomous within the larger society and subject to its own regulations that were based on monastic rules. This mode of functioning first epitomized the greater socio-economic environment: a "closed economic system", where commercial exchanges were rare, and autarky quite common (Le Goff, 1964).

From the $10^{\text {th }}$ to $12^{\text {th }}$ century, with the expansion of orders such as the Clunisians or the Cistercians which became strong land-owning economic forces (Barrière, 1994; Fossier, 1994), the European landscape experienced a gradual and profound evolution. Some monasteries were involved in merchant ${ }^{8}$ or financial land activities, such as real estate management and lending money with interest and a certain degree of spiritual and economic competition (Bouché, 1995) existed between monastic enclaves surrounding these activities.

To manage this growth, a specialization arose in the division of labor between choir brothers, lay brothers and wage earners (Bazin et al., 1998). The search for profits was not the primary goal of monastic organizations, however. They aimed mainly at achieving a minimum level of resources to sustain their autarky ${ }^{9}$.

\footnotetext{
${ }^{8}$ Because of a surplus of primary products (Fossier, 1994). But all this was an "unexpected outcome of social action" as described by Giddens (1984). Cistercians' good administration (conversely to a deliberate strategy) resulted in a surplus.

${ }^{9}$ The comparison between modern firms and middle age monasteries is thus a serious anachronism. Monks were (and still are) together to share their faith and to undertake a spiritual enterprise.
} 
From the late $11^{\text {th }}$ century, Occidental economic growth necessitated the recruitment of new manpower by the Cistercians (Bazin et al., 1998; Racinet, 2007) and as a result they employed lay brothers who were involved in material activities alongside choir brothers. Starting from the $12^{\text {th }}$ century, wage earners ("mercenarii") were also employed. This had the unexpected effect (Bazin et al., 1998), of promoting broader diffusion of technical and administrative knowledge due to the mobility of the affiliated lay population.

Beyond autonomization and specialization, monastic organizations also embody another rupture in collective action, that being formalization. A form of collective action sustained by a system of rules gradually emerged. This is epitomized by the various monastic rules linked to Middle Age congregations. Indeed, these rules included numerous organizational elements, in particular in the fields of organizational control and governance (see Lapierre, 1982). In addition to rules about the "order of psalms", the "measurement of eating", or that of "drinking", the Benedictine Rule specifies how "a brother should be called during a council". A kind of pre-bureaucratic Weberian organization thus arose during the Middle Age period (Kieser, 1987, 1989). Gradually, "customaries" and "status" supplemented the use of rules (Racinet, 1994, 2007). Rules dictated the main spiritual and material principles of collective life. Customaries (appearing between the $8^{\text {th }}$ and $12^{\text {th }}$ centuries) detailed some specific local rules, based on everyday local practices and adaptations of the broader rules. Status determined both rules and customaries (from the $12^{\text {th }}$ century), ex ante or ex post. Thus, "Unlike rules, they did not necessary exist before the development of a community. Unlike customaries, they did not establish a posteriori uses already existing but proclaimed new ones or revise old ones." (Racinet, 2007: 71). Monastic organizations were actually the first rationally designed entities of the Christian occident (Weber, 1978) that can be called protobureaucracies.

\subsection{The institutional influence of the Church on the design and diffusion of new artifacts and techniques related to collective action}

Beyond the development of bureaucracy, the Church and its enclaves have also played an institutional role (in several western countries) in the development and diffusion of various techniques and artifacts. Numerous monks (and priests) participated in the design and diffusion of proto-managerial techniques, in particular in the field of accounting (from the $13^{\text {th }}$ to the $17^{\text {th }}$ centuries). Luca Pacioli (a Franciscan monk), Angelo Pietra (a Benedictine monk) or Ludovico Flori (a Jesuit monk) are worth mentioning (Courtis, 1997; Quattrone, 2004). 
With others, they played a major role in the development, formalization and diffusion of accounting techniques. This should not be a surprise as the ecclesiastic community has a long history of being the erudite community in the occident ("Only the most educated men were admitted as monks", Kieser, 1987: 554).

But more generally, monks have played a role in the formalization of a collective occidental memory through the work of scriptoria, i.e. monastic workshops involved in copying manuscripts. From the $14^{\text {th }}$ century, this role moved from copying manuscripts to writing collective histories. The invention of mechanized printing in the $15^{\text {th }}$ century induced a production of scriptoria focused on legal documents (accounting records, charters or cartularies) tracing the economic activities of the time and contributing to the development and diffusion of new administrative techniques (Bazin et al., 1998).

Monastic enclaves and clergymen also contributed to deeply changing the relationship between collective action and time (Le Goff, 1977; Duby, 1974). From the $6^{\text {th }}$ to the $13^{\text {th }}$ century, bells marked the daily rhythms of life for both monks and for villages. In the $14^{\text {th }}$ century the mechanical clock, a new artifact, was introduced into broad use by monks in order to start and synchronize masses (Landes, 1987). This epitomized a new way to measure time, based on artifacts instead of on nature itself. If all this was originally highly coherent with religious life, time and temporal artifacts enacted by the Church became gradually incompatible with time enacted by merchants in the course of the 14th century (Le Goff, 1977). The finite, material, short-term, valuable time of merchants was very different from the, eternity-oriented, immeasurable, spiritual timeframe of clergymen.

Beyond local clergymen and monastic inventions, the Roman Curia representing the central enclave of the Church, also played a major role in the diffusion of new artifacts and protomanagerial techniques through the coordination of its enclaves all over Christendom. This entity deliberately diffused various liturgical or administrative practices from one territory to another on the basis of an "enclaving" model (Mintzberg and Westley, 1992). It consisted of identifying and distributing relevant local emergent liturgical or administrative practices ( de Vaujany, 2006).

\section{Lastly, the Church also played a major doctrinal role in economics from the Middle Age} period 'till contemporary times. The Curia heavily influenced the emerging rules and artifacts related to economic collective action in Western Europe (see Gomez and Wirtz, 2008 for the case of Germany). It diabolized and then institutionalized commercial practices and the use of interest-based loans during the $12^{\text {th }}$ century (see Le Goff, 1981, 1997). Indeed, at that time, in the face of inevitable economic insurgency which threatened its spiritual 
dominance, the Church adopted a pragmatic position by tolerating some forms of commercial and financial practices. "Indulgences" made it possible for usurers and merchants to hope for the remission of some sins. The creation of Purgatory (during the 12th century) offered 'sinners' (notably merchants and bankers) a new space between hell and heaven. This had a remarkable effect on the rise of capitalism by favoring a new structure of mentalities (Le Goff, 1981, 2001) $)^{10}$.

But beyond its institutional role, the Church, as a specific organizational object, can also provide fruitful lessons for organizational scientists. This will be discussed in the second part of this work.

\section{THE HISTORY OF RELIGIOUS ORGANIZATIONS AS MEANS TO MAKE SENSE OF ORGANIZATIONS AND ORGANIZATIONAL DYNAMICS}

The longevity of the Church and its central entity (the Roman Curia) are of major interest to organization theory (Mintzberg and Westley, 1992; de Vaujany 2006). They make it possible to make sense and question the very idea of long term in the conceptualization of organization. The Curia makes it possible to shed light on a collectivity that has endured multiple institutional and technical evolutions over centuries.

\subsection{The case of religious organizations: a means to make sense of organizational dynamics over the long term?}

Historians and some economists (notably Braudel and the so-called new history), have wondered for a long time about the notion of longue durée (roughly translated as "longterm"). For Braudel (1963), historians have exaggeratedly focused on the notion of "events", putting aside structures and dynamics that corresponded to a longue durée. Some historical

\footnotetext{
${ }^{10}$ Catholic enclaves (in particular congregations) have also been involved in other institutional points of rupture during the modern and contemporary periods. In the $16^{\text {th }}$ century, the counter-reformation ideology of Catholic doctrine favoured the affirmation of accounting and accountability practices (with the Jesuit congregation and other organisations) (Quattrone, 2004; Carmona and Ezzamel, 2006). From the $19^{\text {th }}$ century, the "social doctrine" of the Catholic church (see Laurent, 2007) also contributed to developing a new institutional discourse stemming from the Church about markets and for-profit activities. This took the shape of a set of encyclics (i.e. letters addressed by the Pope to all the bishops of the Church), the first of which was the famous Rerum Novarum by Leo $13^{\text {th. }}$
} 
analyses thus overemphasize successions of short events and short-lived trends and individuals, neglecting broader dynamics of rupture and continuity in collective action. They also overplay the role of broad socio-economic structure in societal change (Vovelle, 1978). According to Le Goff (1978: 37), historians should "build a new scientific chronology which dates more phenomena according to the duration of their effectiveness in history than the starting-point of their production".

But what is said in organization theory about long-term temporal orientations and longterm organizational dynamics? Are there specific long-term moves in secular organizations? Does the notion of "longue durée" (whose econometric background should not be forgotten ${ }^{11}$ ) make sense for the modeling of collective action, in particular organizational action?

Surprisingly, organization theory has already offered a possible answer to these questions. Mintzberg (with Westley) is one of the few authors we found who deals explicitly with the topic by studying the case of "missionary organizations" and their modalities of change in the long run. He has put forward a specific organizational form with a homogenous culture: the missionary organization. From the theorist point of view, missionary organizations display many common traits. They are focused on a specific ideology, i.e. "the rich culture of norms, beliefs, and values that knit a disparate set of people into a harmonious, cooperative entity" (Mintzberg, 1991: 55).

What is the relationship between missionary organizations and religious organizations? Reasonably, it can be assumed that all religious organizations are missionary organizations (as defined by Mintzberg) but all missionary organizations are not necessarily religious ones (Mintzberg mentions Japanese firms as examples of missionary organizations). Nonetheless, the bulk of empirical data used by Mintzberg and Westley (1992) are related to Catholic, Buddhist or Jewish organizations.

With regards to these specific structures, Mintzberg and Westley suggest that change and expansion are done by cellular agglomeration through the setting-up of autonomous units, which then reproduce properties related to an initial community (for example, in the Catholic religion, that of the apostles). The reason for this mode of change is very simple: "very strong ideologies depend on personal contact" (Mintzberg, 1989: 224). Mintzberg and Westley (1992) suggest three types of changes to missionary organizations over long periods: enclaving, cloning and uprooting. Enclaving, also called the "Catholic model" (Ibid: 54)

\footnotetext{
${ }^{11}$ With long term cycles as described by Kondratieff for instance.
} 
consists of accepting new practices in a controlled and isolated way. This "involves the carefully controlled integration of learning within the existing structure, its 'capture', if you will, from a particular enclave" (Ibid: 53). Cloning, also called the "Protestant model" (Ibid: 52 ) is more in line with the morphostatic nature of missionary organizations. It consists of a kind of cellular differentiation and replication of original enclaves into new entities, with extra adaptations to local cultural elements. As Mintzberg and Westley (1992: 55) note, it is "based primarily on exploitation of new learning, if not a new vision than of a new year (or place) in which to execute the old vision." Lastly, uprooting also called the "Buddhist model", (Ibid: 54) consists of regularly cutting members of the missionary organization from their habits, so as to bring them back towards original practices, purified, in order to find the "charismatic intensity of the first stages of the organizational structuring" (Ibid: 56).

But this use of the material provided by the history of religious organizations results in a disturbing but then ultimately, very interesting question: what about the continuity of the object under study? Can we make sense of the history of the Roman Curia by stating that it is a 17 century old organization (Levillain, 1994)? Can one write the history of the Curia as he/she would write the history of Suez or IBM? Many contemporary firms have along life span. A ceteris paribus assumption about their institutional environment is reasonable as is a relative constancy in the vocabulary used for some key terms.

With regards monastic organizations, the question can be focused on the legal architecture, rules, status and customaries. Historical work can then be quite close to the Foucaldian deconstruction of discourse suggested by Hook (2001).

But on the whole, the genealogical perspective defended in this paper renders problematic the very idea of long-term study of organizational dynamics. Besides, "organization" is not a concept at the same level as "self-identity", "sexuality" or other notions at the core of Foucault's studies. It is already a modality of something (collective action). Indeed, the very idea of "history of religious organizations" is not really employed by historians to define their own work ${ }^{12}$. Instead, they describe their research as part of "history of religions" or "history of monasteries".

Nonetheless, focusing on the genealogy of various religious organizations may be interesting as an "institutional tracer". The study of the Roman Curia over a secular period may be very helpful in order to make sense of the genealogy of other notions such as "information" or “information systems" (de Vaujany, 2006) It can also help us answer the question "How has

\footnotetext{
${ }^{12}$ It is more generally an expression we find in handbooks or organization theory papers.
} 
the notion of "information systems" or "governance of information systems" arisen within the Curia?" The response to this question may be a very interesting way to retrace the emergence of Information systems and their institutional environments. Finally, by saying this, we come back to the institutional question emphasized in part 1 .

\subsection{Contemporary history of religious organizations as a means of contrasting various communities and models of collective action}

This last section focuses on the material provided by historians of contemporary religious organizations, and its potential use by organizational scientists.

The Church and its enclaves, like most missionary organizations, have strong socio-cognitive specificities. Actors draw on extremely homogenous interpretive schemes (Bartunek, 1984) and real common values. Religious organizations thus rely on specific models of collective action, embedded in an original community.

In a way, the Middle Age was when "communities" started in the Occident, through the emergence of corporations (abbeys, guilds, universities, professional corporations...) generally called "universitas" (Verger, 1973; Le Goff, 1964). Thus, "Men who were doing the same job and lived close to one another tended naturally to join to represent and defend themselves. These associations did not create a vertical dependency like those which, in the feudal society, linked a man to his lord, but rather formed communities of equal human beings." (Verger, 1973: 99) This community sometimes implied a hierarchy of ranks (apprentice, servant, master), but "it was not at all controlling; from one rank to another, promotion was regarded as normal and was done by means of public examinations" (Ibid).

Later evolutions of Occidental societies may have then resulted in the formation of two distinct communities as viewed from the perspective of the practices in which they were involved: Religious Communities (values and long time-oriented) and Productive Communities (prescription, performance and short-term oriented).

Religious communities $(\mathrm{RC})^{13}$ are 'total'. Individuals are fully involved in the community. There are no real differences between individual and collective actions, no frontier between private and professional life, and a real isonomic status. This is epitomized by Paul's dictum: "There is no Greek or Jew, no slave or free man, there is no man, no woman, as you are all

\footnotetext{
${ }^{13}$ Like those hosted by Cistercians or Carthusian congregations.
} 
one within Jesus Christ" (Gatier, 1994: 179). Monastic communities or sub-communities (in particular Cistercians, see Pacaut, 2005), German guilds (Kiesler, 1989), or Middle Age universities (Verger, 1973) are typically RC. Conversely, Productive Communities (PC) are more partial and interstitial. Individuals are alternatively involved in multiple communities. Many communities within or between contemporary firms are PC. The first type favors reflexivity and solidarity, the second diversity and openness. Still, both may stimulate innovation (this even applies to medieval guilds, but under special conditions, see Kiesler 1989).

On the other hand, identity is the starting point of collective action for the $\mathrm{RC}$, whereas it is more the result of common practices for the PC. Temporal orientation is also completely different, with a secular, everyday, linear orientation for PC and a long term, mythological, cyclical and eternity-oriented vision for RC (see Orlikowski and Yates, 2002).

Given an increasing orientation towards the long term (so-called "corporate strategy") and a simultaneous quest for organizational commitment in firms (Mintzberg, 1991), fuzzier boundaries between private and public spheres in today's liquid world (Bauman, 2000), and a greater sensitivity to ecology and the natural environment (Burgelman, 1991), it seems increasingly likely that contemporary communities within and between firms are shifting towards the model of religious communities (for instance as described by Bazin et al., 1998 for Cistercian communities).

\section{DISCUSSION: SO WHAT?}

\subsection{Towards a reorientationist position based on the history of religious organizations}

According to Foucault (1977: 162), “The purpose of history, guided by genealogy, is not to discover the roots of our identity but to commit itself to its dissipation. It does not seek to define our unique threshold of emergence, the homeland to which metaphysicians promise a return; it seeks to make visible all those discontinuities that cross us." History of religious organizations (we re-use this term for the sake of clarity) may help us identify and make sense of numerous points of rupture in the evolution of collective action. The use of empirical material (such as second hand data) or analysis provided notably by "new historians" treating the case of the Curia, abbeys or other religious organizations, can be extremely useful to 
organization theory. The Church is an actor was and continues to be involved in the institutionalization and genealogy of a new model of collective action and new artifacts deployed for their management. It also presents a long enduring organizational structure likely to help organizational scientists shed light, notably, on change mechanisms (Mintzberg and Westley, 1992; Chaves, 2002), temporal orientations in organizational practices (de Vaujany, 2006), the diffusion of knowledge in organizations (MacGrath, 2002, 2005), the management of resources (Nizet, 2003) and the genealogy of managerial tools (Giffard, 2001; Carmona and Ezzamel, 2006).

By drawing mainly upon the thoughts of major French "new historians" (mainly medievalists), relatively unknown in English-speaking organization theory, this paper presents two new contributions to the fields of organization theory and management.

First, it suggests a means of putting into perspective the most recent evolutions in management science, either by stressing the importance of a neglected institutional factor (religion), or by placing the genealogy of new models of collective action within a broader dynamic begun in the Middle Ages.

Then, this paper also addresses topics that are often put aside in organization theory: the Roman Curia and other specific enclaves of the Catholic Church, such as the Cistercian order. As regards the Roman Curia, the bureaucratization processes it has experienced over centuries (see Levillain, 1994), its practices of strategic intelligence (de Vaujany, 2006), the genealogy of its information systems (de Vaujany, 2006), are all legitimate topics for management and organization theory ${ }^{14}$.

\subsection{Limitations and avenues for further research}

Inevitably, this paper suffers from several limitations.

First, our study is largely based on secondary works, i.e. historical material interpreted by medievalists, relying heavily on the material provided by clergymen themselves (Racinet, $2007)^{15}$ ! This is a classic limitation of many historical accounts. Nonetheless, we would like

\footnotetext{
${ }^{14}$ Beyond this, we believe that the use of "new history" (and its declination to religious organization) can meet a true Foucaldian project as described by Michel Foucault himself in the last stage of his intellectual itinerary (Starkey and Hatchuel, 2002). According to Foucault (1984: 46), "Genealogy will now serve to separate out, from the contingency that has made us what we are, the possibility of no longer being, doing, or thinking, what we are, do or think... It is seeking to give new impetus, as far and wide as possible, to the undefined work of freedom". With regards to rules, the history of abbeys is a way to remind the continuous re-invention of rules, at some points tools used to focus a spiritual quest, at others employed for coercitive or programmatic motives.

${ }^{15}$ Indeed, a major part of our history has been written by monks (Racinet, 2007).
} 
to emphasize that previous fieldwork on religious organizations helped us gain a real familiarity with our research object and its history.

One may also denounce a new type of reductionism related to our approach, and which we did our utmost to avoid. It is important to remember that states, armies, families, etc are also organizations-institutions that contributed to the renewal of collective action and protomanagerial practices. The Church has thus been an actor among others, but whose role is sometimes rendered esoteric in organizational literature (indeed, like that of many other religious organizations). Thus, we share Mutch's reservations regarding the place religious practices occupy in the English context: "It is not to suggest that other influences were not important. Other cultural forces, such as the strength of the tenancy model in English agriculture for example or the influence of Royal chancelleries on French administrative practice, could also be influential. And, of course, to suggest that cultural factors need to be taken into greater account is not to seek to write out economic factors. (...) There are choices in the organization of economic affairs rather than some economically determined model, and in those choices religious belief can be important" (Mutch, 2006b: 7). Furthermore, the proposal of a combination of "organized collective action" and "history of religious organizations" is still insufficiently analyzed in this essay. Further research could shed more light on the link between congregations, towns and corporations in managerial and economic development, or the link between monastic rules and the emergence of a rational-legal system as described by Weber.

Lastly, the "new history" used as a possible resource here defends a reorientationist position that is mainly a French-speaking stream of research. Unfortunately (and surprisingly), most seminal texts have not been translated into English $^{16}$. To overcome this difficulty, collaborations between historians from the English and French-speaking worlds will be necessary.

In keeping with the aforementioned limitations and our two introductory research questions (which are still to be deepened), several avenues for future research can be suggested.

First, the essay could be extended to other religions and religious organizations, as did Mutch (2006b) with the Presbyterian Church, Wasdell (1980) with the Protestant Church, Pesqueux and Dantziger (1991) with Jewish and Protestant organizations, McGrath (2002, 2005) with

\footnotetext{
${ }^{16}$ Even all major writings of Le Goff quoted here, except La civilisation de l'occident medieval.
} 
Irish monastic organizations, and Ali (2005) and El-gamalla (2006) with the Islamic religion. Cross comparisons (as already offered by Tinker 2002 or Bowrin, 2004) could then be extremely useful. If the fields of ethics, economics and sociology have long analyzed the relationship between their research topic and religion, much remains to be done in the fields of management and organization theory (Booth, 1993; Carmona and Ezzamel, 2006; Mutch, 2006b).

Furthermore, it would be very helpful to extend Weber's (1905), Le Goff's (2001) and Perroux's (1965) proposals of the religion-economics relationship to the case of organizations and the evolution of actors' motives. In his famous book The Protestant Ethic and the Spirit of Capitalism, Weber states that "A glance at the occupational statistics for any country in which several religions coexist is revealing. They indicate that people who own capital, employers, more highly educated skilled workers, and more highly trained technical or business personnel in modern companies tend to be, with striking frequency, overwhelmingly Protestant" (1905: 29). This is followed by a long and subtle analysis of the ways by which Protestantism has helped capitalism give birth to its mental structures (Campbell, 2006). As a sign of divine election under Protestantism, economic success was no longer a taboo but rather a social and spiritual necessity. Interestingly, Weber positions religion more as a catalyst than an inhibitor of an ideological system and a major factor in the shift in Occidental motives (Campbell, 2006) ${ }^{17}$. Le Goff has also insisted on religious-economic cooperation by studying the way "an ideological obstacle can impede or delay the development of a new economic system" (2001: 89). He thus adds (p 89): "I believe it's easier to understand this phenomenon by studying the men who are its actors rather than examining only systems or economic doctrines. What I contest is the old history of economics and economic thought which endures to this day. It is all the more ineffective as, in the Middle Ages, there was no specific economic doctrine of the Church, nor Economics as a field of study. (...) By denying the specificity of behaviors and mentalities of the Middle Ages (there are some exceptions), economic histories and histories of modern economic thought have avoided a genuine understanding of the past, and have thus prevented us from illuminating the present with study of the past". Likewise, Perroux $(1964,1965)$ emphasized that economic growth could not be separated from changes in mentalities. These ideologies were themselves inscribed in institutions, notably religious ones. Even if religious institutions and organizations are on the

\footnotetext{
${ }^{17} \mathrm{He}$ also underlines other factors in the development of capitalism, such as the rationalism of scientific research, the simultaneous progress of higher education in mathematics, law and the spirit of enterprise.
} 
margin of many western societies today, the key tenets of long-term historical analyses should not be forgotten. Ideological patterns endure, even if on the surface they seem completely disconnected from old institutions. According to Braudel (1963: 55), "Christianism is an essential reality of occidental life, which marks, even if they are not aware of it, even atheists. Ethics rules, attitudes in front of life or death, conception of work, value of effort, roles of women and children, are behaviors unconnected today to Christianism, but which nonetheless derive from it." The influence of past religious environments on contemporary models of collective action has the potential to serve as the subject of many more fascinating studies.

\section{REFERENCES}

Ali, AJ. (2005). Islamic perspectives on management and organization. Edward Elgar.

Bartunek, JM. (1984). Changing interpretive schemes and organizational restructuring: the example of a religious order. Administrative Science Quarterly. 29(3): 355-372.

Bauman, Z. (2000). Liquid modernity, Cambridge: Polity press.

Bazin, JF., Quenardel, FO., Mouilleron, VR. And Vannier, P. (1998). L'ABCdaire des cisterciens et du monde de Cîteaux, Paris: Editions Flammarion.

Bentley, J. (2003). A Brief History of the Organization: From the Dawn of Civilization to Leadership of Today's Corporation. Bloomington: Editions Universe.

Berlioz, J. (eds) (1994). Moines et religieux au Moyen Age. Paris: Editions du Seuil.

Booth, P. (1993). Accounting in churches: a research framework and agenda. Accounting, Auditing and Accountability Journal. 6(4): 37-67.

Booth, P. and Rowlinson, M. (2006). Management and organizational history: Prospects. Management and organizational history, 1(1): 5-30.

Bowrin, AR. (2004). Internal control in Trinidad and Tobago religious organizations. Accouting, Auditing and Accountability Journal, 17(1): 121-152.

Brady, F.N. (1997). Finding a history for management. Journal of Management Inquiry, 6: 160-67.

Braudel, F. (1978). Histoire et sciences sociales. La longue durée. Annales. 4: 725-753.

Braudel, F. (1963). Grammaire des civilisations. Last edition 1987 Paris: Edition Arthaud.

Burgelman, RA. (1991). Intraorganizational Ecology of Strategy Making and Organizational Adaptation: Theory and Field Research, Organization Science, 2(3): 239-262.

Campbell, C. (2006) Do Today's Sociologists Really Appreciate Weber's Protestant Ethic Essay? The Sociological Review, 54 ( 2): 207-223.

Carmona, S. and Ezzamel, M. (2006). Accounting and religion: a historical perspective. Accounting History. 11(2): 117-127. 
Carruthers, BG. and Espeland, WN. (1991). Accounting for Rationality: Double-Entry Bookkeeping and the Rhetoric of Economic Rationality. The American Journal of Sociology. 97(1): 31-69.

Chaves, M. (2002). Religious organizations: data sources and research opportunities. American behavioral scientist, 45(10): 1523 - 1549.

Courtis, JK. (1997). Accounting History: The Contribution of Osamu Kojima. The Accounting Historians Journal. 24(1): $165-181$

de Vaujany, FX. (2006). Between Eternity and Actualization: the Difficult Co-Evolutions of Fields of Communication in the Vatican. Communications of the AIS. 8(17): 355-394.

Duby, G. (1974). L'an mil, Paris: Folio.last edition of 1993.

El-Gamal, M. (2006). Islamic finance, Cambridge: Cambridge University Press.

Fauchez, A. (1994). Saint Benoît et la révolution des monastères. in Berlioz J. (eds). Moines et religieux au Moyen Age. Paris: seuil, pp. 15-31.

Fossier, R. (1994). Les déviations économiques des Cisterciens. in Pressouyre L. (eds), L'espace cistercien, Paris: Éd. du CTHS, pp. 39-44.

Foucault, M. (1977). "Nietzsche, Genealogy, History". in Bouchard, DF. (Eds), Language, Counter-Memory, Practice: Selected Essays and Interviews. pp. 139-164. Ithaca, New York: Cornell University Press.

Foucault, M. (1979). Discipline and punish: the birth of the prison. London: Penguin.

Foucault, M. (1984). On the genealogy of ethics: an overview of work in progress? in Rabinow, P. (eds). The Foucault reader, New York: Pantheon.

Gatier, PL. (1994). Des femmes au désert? In Berlioz J. (eds). Moines et religieux au Moyen Age. Paris: seuil, pp. 171-187.

Giddens, A. (1984). The Constitution of Society: Outline of a Theory of Structuration, Berkeley: university of California Press.

Giffard, P. (2001). La croissance des Eglises, PhD dissertation defended at the Faculté des études supérieures de l'Université de Montréal in practical theologia.

Gomez, PY. and Wirtz, P. Institutionnalisation des régimes de gouvernance et rôle des institutions socles: le cas de la cogestion allemande. Économies \& Sociétés, série K (Économie de l'entreprise), nº 18.

Hatchuel, A. and Glise, H. (2003). Rebuilding management: a historical perspective. in Adler A., Shani A., Styhre A., Sage, Collaborative Research in Organisations.

Hook, D. (2001). Discourse, knowledge, materiality, history: Foucault and discourse analysis. Theory and psychology. 11(4): 521-547.

Kieser, A. (1987). From Asceticism to Administration of Wealth. Medieval Monasteries and the Pitfalls. Organization Studies, 8: 103-123

Kieser, A. (1989). Organizational, Institutional, and Societal Evolution: Medieval Craft Guilds and the Genesis of Formal Organizations. Administrative Science Quarterly, 34(4): 540-564.

Landes, D. (1987). L'heure qu'il est. Les horloges, la mesure du temps et la formation du monde moderne. Paris: Gallimard. 
Lapierre, JP. (1982). Règles des moines. Paris: Editions du Seuil.

Laurent, B. (2007). L'enseignement social de l'Eglise et l'économie de marché, Paris: Editions Paroles et silence.

Le Goff, J. (1964). La civilisation de l'occident médiéval, Paris: Flammarion.

Le Goff, J. (1977). Au Moyen Âge : Temps de l'Église et temps du marchand. In Pour un autre Moyen Âge: Temps, travail et culture en occident, Paris, pp. 46-65.

Le Goff, J. (1981). La naissance du purgatoire. Paris: Gallimard.

Le Goff, J. (2001). Marchands et banquiers au Moyen Age. Paris: Editions Que Sais-Je ?

Le Goff, J. (1997). La bourse et la vie. Paris: Editions Pluriel.

Le Goff, J. (1978). L'histoire nouvelle. pp. 35-63 in Le Goff J. (eds), La nouvelle histoire. Paris: Editions Complexe.

Levillain, P. (eds) (1994). Dictionnaire historique de la papauté, Paris: Fayard.

McGrath, P. (2002). Early Medieval Irish Monastic Communities: A Premodern Model with Post-Modern Resonances. Culture and Organization. 8(3): 195 - 208

McGrath, P. (2005). Thinking Differently about Knowledge-Intensive Firms: Insights from Early Irish Monasticism. Organization. 12(4): 549-566.

McGregor, D. (1960). The Human Side of Enterprise. Mc Graw Hill.

Mintzberg, H. (1989). Mintzberg on Management: Inside Our Strange World of Organizations. NY: Free Press.

Mintzberg, H. (1991). The effective organization: forces and forms. Sloan Management Review. 32(2): 54-67.

Mintzberg, H. and Westley, F. (1992). Cycles of Organizational Change. Strategic Management Journal. 13: 39-59.

Mutch, A. (2006a). Organization theory and military metaphor: time for a reappraisal? Organization 13: 751769.

Mutch, A. (2006b). The social shaping of management: a practice-based approach to the influence of religion. EGOS Colloquium, Bergen, 6-8 July 2006

Mutch, A. (2006c). The institutional shaping of management: In the tracks of English individualism. Management \& Organizational History. 1(3): 251-271.

Nizet, . (2003). Les ordres religieux du Moyen Age: des organisations fermées? Le cas de Cluny. Archives des sciences sociales des religions, 123: 41-60.

Orlikowski, WJ. and Yates, J. (2002). It's About Time: Temporal Structuring in Organizations. Organization Science. 13: 684 - 700.

Pacaut, M. (2005). Les ordres monastiques et religieux au Moyen Age. Paris: Armand Colin.

Perroux, F. (1964). L'Economie planétaire. Tiers Monde. octobre-décembre 1964, p. 853.

Perroux, F. (1965). Création collective et christianisme du XXème siècle. Cahiers de l'ISMEA. janvier 1965. re-edited in Le Pain et la Parole, Paris, Edit. du Cerf, 1969, p. 323. 
Pesqueux, Y. and Danziger R. (1991). Le contrôle de gestion et l'Eglise. Papier de recherche du CREFIGE (working paper), $\mathrm{n}^{\circ} 9001$.

Quattrone, P. (2004). Accounting for God: accounting and accountability practices in the Society for Jesus (Italy, XVI-XVII centuries). Accounting, organizations and society, 29: 647-683.

Racinet, P. (1994). Règles, coutumiers et statuts (Vème-XIIIème siècle). Brèves considérations historicotypologiques. in Derwich (eds). La vie quotidienne des moines et chanoines réguliers au Moyen Age et temps moderne. Actes du premier colloque international du LARHCOR, Wroclaw-Ksiaz, 30 novembre-4 décembre, vol 1, pp. 31-49.

Racinet, P. (2007). Moines et monastères en occident au Moyen Age. Paris: Ellipes.

Starkey, K. and Hatchuel, A. (2002). The long detour: Foucault's history of desire and pleasure. Organization, 9(4): 641-656.

Swanson, GA. and Gardner, JC. (1988). Not-for-profit accounting and auditing in the early eighteenth century: some archival evidence, The accounting review, 63(3): 436-447.

Tinker, T. (2004). The enlightment and its discontents: antinomies of Christianity, Islam and the calculative sciences. Accounting, Auditing \&Accountability Journal. 17(3): 442-475.

Üsdiken, B. and Kieser, A. (2004), Introduction: history in organization studies, Business History, 46: 321330.

Verger, J. (1973). Les universités au Moyen Age. Paris: Presses Universitaires de France.

Vovelle, M. (2006). L'histoire et la longue durée. pp. 77-102 in Le Goff J. (eds), La nouvelle histoire, Paris: Editions Complexe.

Wasdell, D. (1980). Long range planning and the Church. Long Range Planning. 13(3): 99-108.

Weber, M. (1978). Economy and society. University of California Press.

Weber, M. (1905). The Protestant Ethic and the Spirit of Capitalism. Los Angeles: Roxbury Publishing Company, last edition in 2002.

Wren, DA. (2001). The history of management thought, fifth edition. New York: Wiley.

Yates, J. (1997). Using Giddens' structuration theory to inform business history. Business and Economic History, 26: 159-83. 